\title{
Distribution af video - lige meget hvordan?
}

\section{Diba Markus}

Project manager, cand.mag. $i$

\section{multimedier}

Netsekretariatet, Forskningsnettet diba.markus@forskningsnettet.dk

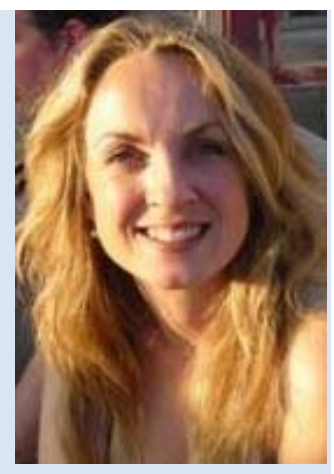

Diba Markus er project manager for Forskningsnettets tjeneste edumedia, der er en løsning til distribution af audiovisuelle medier, som Forskningsnettet i samarbejde med Danmarks Radio og Statsbiblioteket og støttet af Danske Fag-og Forskningsbiblioteker har udviklet til de danske universiteter. Via udviklingen af edumedia har Diba indsigt i såvel institutionernes behov som forskningsbibliotekernes perspektiv i relation videodistribution. Derudover har Diba også et godt kendskab til de europæiske institutioners og forskningsnets initiativer på området via TERENA (TransEuropean Research and Education Networking Association). 


\section{Abstract}

Artiklen omhandler løsninger til distribution af video og de faktorer, der kan være udslagsgivende, når man som underviser eller universitet skal vælge, hvilken man vil gøre brug af.

De kommercielle løsninger såsom YouTube m.fl. er kendt af de fleste. Hvad færre måske ved er, at der eksisterer alternativer. På europæisk plan har en række institutioner og forskningsnet, herunder det danske, således valgt at lave deres egne løsninger. Der er afgørende forskelle i disse hhv. kommercielle og ikke-kommercielle videodistributionstjenesters tilgange til problemstillinger vedrørende adgangsbegrænsning, ophavsret, metadatering og bevaring samt kvalitetssikring af indhold - forskelle, der for en stor del udspringer af deres respektive opdrag og muligheder for brugerautentificering. Kun de færreste af alternativerne kan bruges af danske studerende og universitetsansatte. Som der argumenteres for $\mathrm{i}$ artiklen, er disse problemstillinger imidlertid vigtig baggrundsinformation, når der skal tages stilling til, hvordan man bedst distribuerer videoressourcer.

I artiklen beskrives overordnede fællestræk ved hhv. de kommercielle og de ikke-kommercielle distributionsløsninger, og de helt grundliggende forskelle mellem dem diskuteres.

\section{Indledning}

Med nærværende artikel vil jeg gerne give læseren en forståelse af, hvilke problemstillinger der kan være vigtige i universitetssammenhæng i forhold til valg af videodistributionsløsning, hvad enten man nu er underviser, repræsenterer en mindre enhed eller et universitet.

Når jeg specifikt diskuterer videodistribution og ikke mediedistribution generelt, skyldes det, at etableringen af en on demand videodistributionsservice til bare et beskedent antal samtidige brugere indebærer en betydeligt større ressourcemæssig satsning i form af specialiseret hardware, software og teknisk know-how end fx opsætningen af et online billedgalleri. Dermed involverer distribution af video automatisk flere strategiske overvejelser.

Der findes en nærmest overvældende mængde websites, der gratis eller mod betaling tilbyder at "hoste" brugergenereret video, dvs. lagre og også eksponere dem via deres webfrontend: YouTube, Joost, Miro, DailyMotion for blot at nævne nogle. Her kan man se/afvikle videoerne online og ofte også arbejde med dem vha. diverse værktøjer. Muligheder er der med andre ord rigeligt af. 
At der er så mange forskellige videodistributionsmuligheder, er imidlertid både godt og skidt. Godt fordi det fremmer anvendelsen af denne type ressourcer i og med, at systemerne sætter underviseren, forskeren eller kommunikationsmedarbejderen i stand til selv at distribuere dem. Skidt fordi det også betyder en større risiko for at "smide barnet ud med badevandet".

Her er en vigtig pointe, at de færreste kommercielle videodistributionstjenester har et langsigtet strategisk perspektiv, hvor fx krav til undervisningsmæssig kvalitet og relevans eller den fremtidige nyttiggørelse af videoerne er i fokus. De fleste er tværtimod social network sites med et underholdningsmæssigt sigte. Sat på spidsen kan de uddannelsesmæssige potentialer ved disse tjenester nærmest betegnes som et "lykkeligt biprodukt". I erkendelse heraf bruger en række institutioner og forskningsnet rundt om i Europa og USA store ressourcer på at udvikle skræddersyede alternative løsninger, hver med udgangspunkt i dét, de hver især vurderer lige netop er deres institutions eller universitetssektors behov. Omvendt har de kommercielle tjenester nogle forcer fx mht. udbredelsesgrad - de er allerede slået massivt igennem i de studerendes forbrugsmønstre.

Hvis man anlægger den betragtning, at video produceret med undervisning og formidling på universitetsniveau for øje ikke er "grå litteratur" (dvs. noget, der ikke i traditionel forstand bliver publiceret og dermed ikke rigtigt "tæller"), men faktisk er værdifulde ressourcer, som hver især er produktet af en intellektuel proces og en betydelig mængde tid og kræfter, begynder det således at blive interessant, hvordan "guldet" bliver forvaltet - herunder hvordan det bliver distribueret.

Min pointe er her ikke, at kommercielle løsninger er noget skidt, men derimod at det er vigtigt, at man har et reflekteret forhold til, hvilke distributionsløsninger man bruger hvornår.

\section{Forskellige typer videodistributionstjenester}

I det følgende beskriver jeg nogle af fællestrækkene ved hhv. de kommercielle videodistributionstjenester og løsningerne udviklet af institutionerne og forskningsnettene. De i dette afsnit to sidstnævnte typer distributionsløsninger er på mange måder "variationer over samme tema", men der er imidlertid væsentlige forskelle i målgruppe, udbredelse og teknisk implementering, der gør det relevant at beskrive dem hver for sig.

\section{De kommercielle}

Der er en lang række kommercielle tjenester ud over de allerede nævnte, som det vil føre for vidt at opliste her. I stedet vil jeg henvise til listen over 
video sharing-websites på Wikipedia, som - selvom den er lang - helt givet ikke favner dem alle ${ }^{1}$. Ønsker man et hurtigt overblik over fx tekniske ligheder og forskelle på en lang række af disse tjenester, er Wikipedia igen et godt sted at starte ${ }^{2}$. Fælles for tjenesterne er, at de er reklamefinansierede og/eller abonnementsbaserede, men at de på ægte web 2.0-vis gør det muligt for enhver med internetadgang at blive indholdsleverandør og dermed distribuere.

Derudover er det mest iøjnefaldende fællestræk, at de ofte har en begrænsning i forhold til upload (filstørrelse og/eller varighed). Fx har YouTube en begrænsning på 1 GB eller 10 min pr. video ${ }^{3}$. iTunesU har en maksimumgrænse på $500 \mathrm{~GB}$ per institution ${ }^{4}$. Endvidere har mange af dem af båndbreddehensyn realiseret i form af en relativt hård komprimering af videodata, hvilket traditionelt har været ensbetydende med ringe billedkvalitet. Den hurtige udbredelse af effektive codecs såsom H.264/MPEG-4 har imidlertid på kort tid ændret den sag, så selv YouTube nu kan streame i HD (720p).

\section{Institutionernes}

En oversigt over en lang række forskellige distributionsløsninger udviklet af højere læreanstalter overalt i verden kan findes på Opencast-projektets hjemmeside ${ }^{5}$.

Institutionernes distributionsløsninger er i sagens natur udviklet med henblik på at sætte institutionernes egne brugere i stand til at distribuere. Dermed kan de - modsat de kommercielle løsninger - ikke anvendes af alle, i hvert fald ikke til distribution. Derimod tillader de som regel helt eller delvist andre at "forbruge" indholdet, idet en del af formålet med dem ofte er ekstern kommunikation.

Derudover er et fællestræk ved mange af disse tjenester, at de ikke blot fokuserer på distribution/publicering, men også på produktionsprocessen, dvs. de inkluderer en produktionsplatform til fx automatiseret video-, audio- og slideshow-optagelse. En del løsninger er open source, som fx schweiziske REPLAY ${ }^{6}$, og kan altså anvendes og modificeres af andre

1http://en.wikipedia.org/wiki/List_of_video_sharing_websites $2 \mathrm{http}: / /$ en.wikipedia.org/wiki/Comparison_of_video_services 3 http://help.youtube.com/support/youtube/bin/answer. py?answer=55743\&topic=166 12

4 Jf. pkt. 3.2 i kontrakten (service agreement) http://campuscio.mnscu.edu/MeetingDocs/200803020-0321/SCSU-iTunesUContract.PDF $5 \mathrm{Jf}$. http://www.opencastproject.org/showcases $6 \mathrm{http}: / / \mathrm{www} \cdot$ replay.ethz.ch/ 
institutioner, men ellers er det hjemmeudviklede ("homegrown") løsninger skræddersyet til det enkelte universitet.

\section{De forskningsnet-baserede}

Et nationalt forskningsnet er en non-profit-organisation i offentligt regi, der leverer infrastruktur i form af højhastighedsnet og relaterede netværksbaserede tjenester til det pågældende lands universiteter og forskningsinstitutioner. I den egenskab kan et forskningsnet varetage tværinstitutionelle interesser fx i relation til distribution af video.

Mindst tre europæiske forskningsnet har udviklet sådanne nationale videotjenester. Det er schweiziske SWITCHcast ${ }^{7}$, og hollandske SURFmedia ${ }^{8}$, der har været i drift i hhv. 4 og 6 år, og så danske edumedia ${ }^{9}$, der gik i drift efteråret 2008. De er alle tre designet med henblik på at fungere som fælles tjenester for de respektive landes universiteter, således at det enkelte universitet ikke behøver - men kan have - sin egen distributionsløsning. Fælles for dem er, at de fra start har satset på højkvalitetsvideo (indtil videre dog kun dvd-kvalitet), simpelthen fordi der er en større båndbredde på et forskningsnet.

Fælles for de omtalte forskningsnet er satsningen på nationale såkaldt fødererede autentifikations- og autorisationsinfrastrukturer, der er en slags "login-samarbejder" for de respektive landes universiteter.

En sådan infrastruktur sætter en person, der kan autentificeres (dvs. genkendes som værende tilknyttet et universitet i det pågældende samarbejde) i stand til at logge ind på og bruge en hvilken som helst af tjenesterne, der udbydes i samarbejdet, kun med brug af sit institutionslogin - forudsat altså at personen kan autoriseres (dvs. har lov til at bruge den givne tjeneste). Det smarte er, at det er nemt (brugeren skal kun huske ét login) og sikkert (loginet bruges kun på institutionens hjemmeside, hvilket betyder at autenficeringen er institutionernes ansvar, og at login-informationen ikke videregives til 3. part). Set fra tjenestens perspektiv betyder det, at der trækkes på institutionernes databaser, at der er helt styr på, hvor brugerne kommer fra. Som jeg kommer ind på i det følgende, giver netop dét set up nogle helt unikke muligheder i relation til distribution af videoressourcer.

Den danske autentifikations- og autorisationsføderation hedder WAYF, og er allerede i funktion med en række tilkoblede tjenester ${ }^{10}$. edumedia er

$7 \mathrm{https}: / /$ cast.switch.ch/ 8 http://www.surfmedia.nl 9 https://www.edumedia.dk/ 10 https://www.wayf.dk/ 
med i dette samarbejde, men er i skrivende stund dog endnu kun i et testforløb. De hollandske og schweiziske tjenester kan selvfølgelig ikke anvendes af brugere ved danske universiteter, så når jeg beskriver dem, er det kun for at illustrere en trend, som underbygges af, at flere andre europæiske forskningsnet er på vej med tilsvarende løsninger.

\section{Metadata - hvorfor er det vigtigt?}

En markant forskel, når man sammenligner kommercielle og ikkekommercielle videodistributionstjenester, er tilgangen til metadata.

Helt jordnært sagt, giver metadata (data om data) i form af $\mathrm{fx}$ emneord, beskrivelser mv. den enkelte videoressource værdi. For uden denne tekstlige information er det så godt som umuligt for andre at søge og fremfinde ressourcen. Med andre ord er denne type af metadata lig med søgemuligheder.

Derudover bidrager metadata med kontekst og faciliterer dermed forståelsen af videoens budskab og indhold, ligesom det er et vigtigt redskab til relevansvurdering, hos den der har fremfundet ressourcen. I den forstand beriger metadata videoressourcen. Derfor er metadata vigtigt - specielt i et akademisk miljø, hvor det forudsættes, at man kan sortere og evaluere information. Værdien af en ressource afhænger således i høj grad af kvaliteten af metadata. Hvor der er en målsætning om, at en videoressource skal kunne genanvendes også uden for den specifikke kontekst, den er tænkt ind i, fx et bestemt undervisningsforløb, kan "forrentningen" på den megen tid, kræfter og intellektuelle arbejde, der er investeret i den enkelte videoressource, således risikere at blive lav, hvis den ikke er ordentligt metadateret, og andre derfor ikke kan fremsøge eller relevansvurdere ressourcen.

Nu kan man diskutere, hvad kvalitet i relation til metadata er. Bibliotekaren forstår metadata som data, der på en struktureret måde beskriver en ressources karakteristika og indholdet af den. I bibliotekssammenhæng fremkommer metadata ideelt set ved automatisk generering (maskinel dataanalyse) eller ved manuel inddatering foretaget af en person med særlig kompetence inden for metadatering - en person der dermed fungerer som en slags forvalter af metadata og "garant" for kvaliteten af den. Metadateringen er dermed stærkt styret.

De kommercielle videodistributionsløsninger har en lidt anden tilgang til metadata. Her er en del også autogenereret, mens andet fremkommer ved at den, der uploader videoen selv metadaterer. Men det væsentligste karakteristikum er formodentligt vægten på 3. parts brugergenereret metadata, der fremkommer ved at andre fx aktivt kommenterer 
(annotations), kategoriserer (tags) og rangerer (user rating) eller på anden måde interagerer med ressourcerne, hvorved de mere indirekte bidrager med data fx til afspilningsstatistik og link-referencer (pagerank).

I universitetssammenhæng kan denne form for metadata synes mere overfladisk og af ringere værdi end dem, bibliotekaren forvalter. Men det behøver ikke være tilfældet. Fx rummer kommentarfunktionen muligheden for, at fagfæller og eksperter inden for et givent område kan yde vigtige bidrag til forståelsen af indholdet af den givne videoressource. På samme måde er user rating formodentligt også et udmærket redskab til relevansvurdering.

Blandt de institutioner og forskningsnet, der har udviklet videodistributionsløsninger, er der langt fra enighed om, hvilke metadataelementer, der er vigtige, eller hvilken metadatastandard ${ }^{11}$, der er den bedst egnede. Det, de til gengæld er enige om, er, at metadata og standarder er vigtige. "Bibliotekstilgangen" til metadata er således klart fremherskende, måske fordi den appellerer til et akademisk miljø. Men man finder dog også en afsmitning fra de kommercielle social network sites, idet $\mathrm{fx}$ både det hollandske og det schweiziske forskningsnets videoløsning har en kommentar- og rangeringsfunktion.

En sidegevinst ved den standardiserede tilgang til metadata er i øvrigt, at den giver mulighed for at udveksle dem, sådan at underviseren eller den studerende vil kunne søge i en pulje af ressourcer, som i realiteten befinder sig på forskellige lokaliteter (hvad der med et biblioteksudtryk kaldes samsøgning). Dermed kan underviseren få adgang til endnu flere videoressourcer. Metadataudveksling er en mulighed, der er stor interesse for blandt universiteterne og forskningsnettene både i og uden for Europa ${ }^{12}$, men endnu er de tværinstitutionelle og internationale initiativer i sin spæde start, mens den allerede er godt i gang inden for de europæiske kulturavsinstitutioner ${ }^{13}$.

Den slags koordinerede samarbejder er næppe noget, man kommer til at se blandt de kommercielle videodistributionstjenester. Det ville konflikte med den enkelte tjenestes behov for at tilbyde noget unikt, der kan tiltrække og fastholde brugere. Her har specielt kulturarvsinstitutionerne (i kraft af

11 For en forklaring på, hvad metadata-standarder er, og hvordan de bliver til, se http://www.dcc.ac.uk/resource/standards-watch/what-are-metadata-standards/ 12 Se fx de forskellige indlæg på TERENAs nyligt afholdte Media Management and Distribution Workshop http://www.terena.org/activities/media/ws1/programme.html eller Open cast http://www.opencastproject.org/project/metadata. 13 Se fx http://europeana.eu/portal/aboutus.html 
deres public service-forpligtelse) og til dels også

uddannelsesinstitutionerne et helt andet, mere "altruistisk" opdrag, og dermed helt andre muligheder for at agere, selvom den stadigt skærpede konkurrencesituation blandt sidstnævnte måske er ved at ændre den sag.

\section{Adgangsbegrænsning - et tveægget sværd}

Adgangsbegrænsning i forhold til læringsressourcer lyder måske umiddelbart som noget negativt. Imidlertid kan muligheden for at begrænse adgangen til en ressource være dét, der overhovedet gør den tilgængelig i undervisningsmæssig sammenhæng. Selvom det lyder som en selvmodsigelse, kan adgangsbegrænsning dermed være det, der giver adgang til mere.

Et oplagt eksempel er optagelsen af et kirurgisk indgreb, som pga. risikoen for fx persongenkendelse ikke må ligge frit tilgængeligt på internettet. På tilsvarende vis kan ophavs- eller aftaleretlige forhold nødvendiggøre adgangsbegrænsning. Adgangsbegrænsningen handler her alene om, at adgangen til ressourcen er betinget af, at personen, der ønsker at tilgå den, fx kan dokumentere tilknytning til universitetssektoren generelt eller et bestemt universitet, fagområde, undervisningshold mv. og/eller eventuelt et bestemt uddannelsesniveau. Der er med andre ord tale om objektive kriterier.

Her har en institutionsudviklet løsning eller en løsning, der bygger på en samlet autentifikations- og autorisationsmekanisme en stor fordel. Det har den i og med, at den trækker på institutionens databaser (eller - i tilfældet med den samlede løsning - flere institutioners databaser) over studerende og ansatte. Det forhold betyder nemlig, at det over for fx rettighedshavere kan garanteres, at de registrerede brugere udelukkende kommer fra den pågældende institution/institutionerne, og at ressourcerne ikke tilgås af andre end dem, der har ret til det ${ }^{14}$.

Dér kan institutionerne og forskningsnettene noget, de kommercielle aktører ikke kan. Når Apples iTunesU (som formodentlig eneste undtagelse) rent faktisk tilbyder et medlemsuniversitet en sådan eksakt defineret adgangskontrol, kan det kun lade sig gøre, fordi universitetet accepterer, at iTunes' infrastrukturen bruges end-to-end ${ }^{15}$, hvilket må siges

14 Granulariteten, dvs. det niveau brugerne kan skelnes fra hinanden på, afhænger dog af, hvordan autentifikationen er implementeret på det enkelte universitet - om det kun er tilknytningen til en institution, der kan verificeres, eller om det også er muligt at verificere fx kursustilknytning eller studieniveau.

15 I dette set-up foretages autentificeringen (afklaringen af hvem brugeren er) af universitetet selv, mens autorisationen (afklaringen af hvad brugeren må) foretages af iTunes U/Apple på baggrund af de privilegier, institutionen har givet den 
at være et eksempel på en usædvanligt tæt kobling mellem kommercielle og ikke-kommercielle interesser.

Nogle kommercielle videodistributionsløsninger som fx Vimeo og Phanfare giver også mulighed for at selektere i, hvem der har adgang til ens video, men det er med henblik på "privacy". Altså at en bruger kan etablere sit eget private, fuldstændigt vilkårligt sammensatte "community" omkring en video eller samling af videoer ${ }^{16}$. En sådan funktion kunne ganske givet også være både nyttig og relevant i universitetssammenhæng fx til videobaserede opgavebesvarelser, hvor produktionerne ikke må ligge frit tilgængelige. Den er imidlertid uanvendelig som generel mekanisme til at skelne mellem brugere på baggrund af fx uddannelsesniveau.

Det forhold, at institutionerne (og i kraft af dem også forskningsnettene) har fuldstændig styr på, hvem brugerne af deres distributionstjenster er, betyder således i et større perspektiv formodentligt forbedrede muligheder for at indgå aftaler med rettighedshaverorganisationer, public serviceinstitutioner og undervisningsforlag mv. om adgang til beskyttet undervisningsrelevant indhold.

\section{Rettighedshåndtering - er det vigtigt?}

Det er langt fra alle, der har et bevidst forhold til ophavsret, og det kan også være et svært område at sætte sig ind i. Ikke desto mindre har ophavsretten praktisk betydning, når man distribuerer video - og specielt $\mathrm{i}$ undervisningssammenhænge, hvor der med rette er en forventning om, at ressourcerne er lovlige, og således kan bruges på legal vis.

Ophavsret er den ret, der beskytter ophavsmænd til filmværker, litterære værker, kunstværker m.v. mod at disse værker kopieres, sælges eller anvendes på anden måde, der strider mod ophavsmændenes interesser ${ }^{17}$. Ophavsretten beskytter dermed ens "kreativitet". Hvis man ikke modificerer den på nogen måde, betyder det, at man har alle rettigheder til sit værk. Fuld ophavsret kan imidlertid være for restriktiv, hvis man ønsker at dele sin video eller tillade, at andre bruger den.

Med licensmodeller som Creative Commons kan man imidlertid ændre de ophavsretlige betingelser, der gælder for ens video, fra 'all rights reserved'

pågældende bruger, se http://deimos.apple.com/rsrc/doc/iTunesUAdministratorsGuide/AdministeringYouriT unesUSite/ chapter_6_section_7.html\#//apple_ref/doc/uid/AdminGuide-CH6-SW2 16 Se fx http://www. vimeo.com/help/faq\#privacy settings 17 Definition fra Inforkiosk.dk, der er Kulturministeriets initiativ til at udbrede kendskabet til ophavsret (http://www.infokiosk.dk/sw81171.asp). 
til 'some rights reserved'. Dermed beholder man sin ophavsret intakt samtidig med, at man tillader, at andre kan bruge og eventuelt ændre ens video under bestemte betingelser. Creative Commons giver således mulighed for at sammenstykke en individuel licens med så mange eller så få restriktioner, som man ønsker. Ideen er at undgå de barrierer, den nuværende ophavsretslov opsætter for deling af fx videobaserede læringsressourcer.

Ophavsret er desværre noget, de færreste kommercielle video distributionstjenester hidtil har bekymret sig om, og som de derfor heller ikke har nogen mekanismer til at håndtere. Men de er på vej - i hvert fald hvis man tager YouTube, der pt. i gang med at teste muligheden for at bruge Creative Commons-licensen som strømpil ${ }^{18}$. I modsætning hertil har de forskningsnet-drevne tjenester et klart fokus på problemstillingen omkring ophavsret, og har på et tidligt tidspunkt inkorporeret muligheden for at licensere værkerne under fx Creative Commons.

Autentifikations- og autorisationsmekanismen spiller også en interessant faktor i forbindelse med hævdelse af ophavsretten. Løsninger, der trækker på institutionernes databaser over studerende og ansatte, har således rigtig gode muligheder for at assistere ved opklaring af eventuelle tilfælde af overtrædelse af ophavsretten. For brugerne vil den omstændighed formodentligt medvirke til en øget opmærksomhed på de ophavsretlige forhold omkring det indhold, de distribuerer eller anvender via den pågældende tjeneste.

Og det er vigtigt at forholde sig til ophavsret. I undervisnings- og formidlingssammenhæng vil jeg således anbefale kun at bruge distributionstjenester, der understøtter rettighedshåndtering. Det er vigtigt for at sikre dels ens egne rettigheder, hvis man distribuerer, og dels at man selv er lovlig, hvis man anvender andres værker - fx embedder en anden undervisers video på sin kursushjemmeside.

\section{Kvalitet og kontekst - er der en sammenhæng?}

Kvalitet i forhold til videobaserede ressourcer kan være mange ting og kan relatere sig til såvel teknik som indhold. Imidlertid bliver forskellene i teknisk kvalitet stadig mindre og mindre - fx bliver outputkvaliteterne mere ens i takt med, at video codecs bliver mere effektive, og de private internetudbydere skruer op for båndbredden, ligesom servicekvaliteten bliver mere ensartet, fordi tjenesterne over én kam bliver mere og mere professionaliserede. Derfor bliver det hurtigt mere interessant at diskutere

18 Jf. indlægget "YouTube Goes Offline", der findes på YouTubes egen blog http://www.youtube.com/blog?entry=Mp1pWVLh3_Y 
kvalitet i forhold til indhold, og om der er en sammenhæng mellem (den oplevede) kvalitet og konteksten, indholdet præsenteres i.

I europæisk sammenhæng er der blandt institutionerne meget blandede holdninger til, hvorvidt kommercielle videodistributionstjenester er velegnede til distribution af deres videoressourcer. Specielt YouTube deler vandene.

Nogle universiteter er fortalere for at bruge YouTube ud fra et argument om, at "det jo alligevel er her, de unge kommer", og at det i denne sammenhæng tilmed har en positiv signalværdi, at institutionen "er på YouTube". YouTube er her med andre ord synonym med en enorm eksponeringsflade (og en oplagt rekrutteringsmulighed), og det faktum bør man ikke forklejne. Et andet pro-argument er, at YouTube er en kilde til information, som enhver anden, og at de studerende (og kommende studerende) udmærket er i stand til at kende kvalitetsindhold, når de ser det. Nogle gange er satsningen på YouTube også (eller alene) begrundet $\mathrm{i}$ økonomi og den omstændighed, at denne tjeneste formodentlig er den billigst tænkelige distributionsløsning i forhold til udbredelsesgrad.

Andre universiteter gør, hvad de kan for aktivt at undgå, at deres ressourcer "ender på YouTube" ud fra et argument om, at ressourcernes værdi forringes i en "useriøs" kontekst bestående af hjemmevideoer, mobiltelefonoptagelser og ulovligt distribuerede musikvideoer.

På YouTube er der imidlertid også meget indhold med uddannelsesmæssig værdi på eksempelvis den til formålet dedikerede "educational channel". Sidstnævnte har dog den svaghed, at de undervisningsrelevante ressourcer er blandet op med, hvad der må betegnes som mindre seriøst indhold, hvilket er med til at give kritikerne vind i sejlene. Det billede kan dog formodentligt ændre sig lynhurtigt, hvis YouTube vælger at foretage en strategisk satsning på uddannelsesområdet (laver en "YouTubeU"), sådan som Apple gjorde det med iTunesU i maj $2007^{19}$.

Eksemplet med YouTubes educational channel aktualiserer spørgsmålet om, hvordan en distributionstjenste sikrer, at den indholdsmæssige kvalitet er så god som muligt. Én mulighed er, at tjenesten gennem et reviewsystem 100 \% bestemmer, hvad der må publiceres. En anden tilgang, som fx edumedia benytter sig af, er at forlade sig på "selv-censur" i kombination med adgangsbegrænsning. Kravet om autentificering sikrer her, at en bruger, der distribuerer, ikke kan være anonym. Rationalet og håbet er så, at det forhold automatisk vil betyde en vis selvcensur, en vis 
selvkritik, der igen bidrager til at sikre den indholdsmæssige kvalitet på tjenesten, til gavn for alle der bruger den.

I den sammenhæng er det værd at bemærke, at der kan være forskel på, hvor restriktiv udvælgelsen er. I edumedias eksempel tillader vi også, at studerende distribuerer. Denne "demokratiske" tilgang åbner for andre pædagogiske scenarier end en tilgang, hvor kun undervisere og andre ansatte kan distribuere. Muligheden er oplagt i forbindelse med opgaver, hvor de studerende som en del af opgavebesvarelsen skal producere en video eller dokumentere feltarbejde, fors $\varnothing$ g, diverse processer, etc. Muligheden kunne også være relevant fx til sprogtræning, hvor de studerendes orale præstation evalueres eller i forbindelse med træning $\mathrm{i}$ præsentationsteknik. Endelig kunne man forestille sig, at de studerende fik valget mellem at besvare opgaver skriftligt eller mundtligt via video, de så uploadede til systemet.

\section{Hvad betyder en bevaringsstrategi?}

Spørgsmålet om, hvad der udgør en god distributionstjeneste, og hvilken man skal satse på, handler ikke kun om distribution, men også om bevaring.

Tag eksemplet med optagelsen af forskeren, der fortæller om, hvordan hun nåede til sit opsigtsvækkende forskningsresultat. Videoen er lagt på nettet, fordi det er god PR og noget, der tiltrækker studerende. Den er imidlertid også et historisk dokument, der måske en dag opnår samme dokumentariske stjernestatus som optagelserne af Niels Bohr. Men hvordan kan andre finde videoen om 5-10 år, og kan de afspille den til den tid? Med andre ord: Har distributionstjenesten en bevaringsstrategi?

En bevaringsstrategi indebærer en bevidst stillingtagen til, hvordan de digitale ressourcer bevares og hvor længe. Da enhver videoproduktion jo i større eller mindre grad repræsenterer en investering, er muligheden for en "forrentning" over tid essentiel, og så bliver overvejelserne om bevaring vigtige. En bevaringsstrategi er derfor noget, som distributionstjenesten såvel som institutionen bør have, og som den enkelte bruger bør have mulighed for at få indsigt $\mathrm{i}$.

Blandt tjenesterne kan der være afgørende forskelle på bevaringsstrategi. Nogle gange opererer en tjeneste med en række filformater, den har forpligtet sig på at "vedligeholde", sådan at en video kan afspilles med den til enhver tid tilgængelige teknologi. Den strategi anvender fx edumedia. Andre gange oplagrer en tjeneste kun den originale fil, uden i øvrigt at garantere, at videoen kan tilgås senere. Atter andre tjenester oplyser ganske enkelt ikke noget om, hvad brugerne kan forvente i forhold til 
bevaring af deres materiale. Det lader fx til at være tilfældet med YouTube. I hvert fald har jeg til dato ikke kunnet finde nogen information vedrørende bevaring i brugsbetingelserne eller fremsøge sådan en information trods grundig research. Tilsvarende med iTunes U.

Nu kan der - afhængigt af brugscenarie - være stor forskel på den enkelte ressources "levetid" (livscyklus). Fx vil on demand-udgaven af sidste uges forelæsning formodentligt være mindre interessant det efterfølgende semester, hvor faget bliver udbudt igen, og forelæsningsrækken starter forfra. Omvendt har optagelsen af den højtprofilerede forskers gæsteforelæsning formodentligt en udløbsdato, der ligger betragteligt længere ude i fremtiden.

Set fra en pragmatisk synsvinkel kunne man således argumentere for, at "efterspørgslen" afgør behovet for bevaring. Sådan kan det imidlertid ikke gøres op i praksis - der er nødt til at være klare linjer for, hvad der kan forventes af tjenesten, for at institutionen, underviseren eller forskningsformidleren kan tage sine forholdsregler. Her synes jeg, det er værd at diskutere betydningen af det kommercielle aspekt hos iTunesU, YouTube m.fl. og det anderledes perspektiv, det giver. Der gives ingen garantier, og det konflikter - efter min mening - med institutionernes langsigtede forpligtelser og strategier.

\section{Kan man bruge et fælles arkiv til noget?}

Når en institution vælger at lave sin egen videodistributionsløsning, har det selvfølgelig at gøre med, at institutionen ønsker at gøre det så nemt som muligt for dets undervisere, forskere m.fl. at distribuere video. Ved at have sin egen løsning sikrer institutionen sig også, at distributionen sker på en måde, som den finder passende jf. kravene til metadatering, adgangs- og rettighedshåndtering, kvalitet og bevaring. En væsentlig sidegevinst er, at institutionen hermed opnår et fælles internt arkiv som alternativ til situationen, hvor ressourcerne ligger spredt ud på forskellige storages, og hvor der ikke er nogen ensartet tilgang til fx valg af formater, adgang og bevaring. Ved at samle/pulje videoressourcerne, kan de søges på og (gen)anvendes mere effektivt. Den strategi giver rigtig god mening, når det handler om at accelerere brugen af denne type ressourcer - om at forvalte guldet.

Det er langt hen ad vejen de samme overvejelser, som ligger til grund for løsningerne, der er udviklet af de tre europæiske forskningsnet. Der er imidlertid et tværinstitutionelt perspektiv, som gør dem interessante. Sådanne distributionsløsninger eller arkiver (repositories) har nemlig potentialet til at udgøre et fælles referencepunkt for alle de tilknyttede institutioner på én gang. Dermed kan de bidrage til fremme spredningen, 
udvekslingen og anvendelsen af sådanne værdifulde ressourcer på tværs af institutionerne.

I den sammenhæng er det i øvrigt værd at bemærke, at edumedia tilhører en lille, eksklusiv gruppe af distributionsløsninger, hvor det er muligt at uploade ikke alene video, men også audio, billeder og Flash-animationer (.swf) (plus der er en upload-kategori til alt dét, der ikke ligger inden for de førnævnte kategorier). Det betyder, at underviseren, der har behov for at distribuere forskellige medietyper, faktisk vil kunne nøjes med at deponere sine medier ét sted i stedet for at anvende flere tjenester. Dermed er fællesarkivet taget et skridt videre. I modsætning hertil opererer langt de fleste andre distributionsløsninger - kommercielle som ikke-kommercielle - kun med én medietype eller måske to. En af de få undtagelser blandt de kommercielle løsninger er Ipernity ${ }^{20}$.

I relation til tværinstitutionelle løsninger handler et andet lige så lavpraktisk perspektiv om, at undervisere og forskere sjældent nøjes med at være tilknyttet én institution hele deres karriere. Ofte skifter de én institution ud for en anden, eller er tilknyttet flere på én gang, ligesom de samarbejder på tværs af institutioner. Her har et tværinstitutionelt arkiv helt indiskutabelt en fordel. Derudover har et sådant fælles arkiv ideelt set et vist potentiale i forhold til at modgå "dobbeltarbejde" blandt institutionerne. Fx er der jo i princippet ikke grund til at lave to instruktioner fx i korrekt anlæggelse af drop på håndroden, med mindre der er tale om forskellige metoder eller teknologier.

\section{Konklusion}

Når institutioner og forskningsnet udvikler egne videodistributionsløsninger, står de langt hen ad vejen ikke alene på skuldrene af de tilsvarende kommercielle web2.0-agtige fænomener, men også til en vis grad i et konkurrenceforhold til dem.

Jeg har i artiklen forsøgt at give et balanceret billede af nogle af de styrker og svagheder, begge hold løsninger har i forhold til metadatering, rettighedshåndtering og bevaringsstrategi samt kvalitetssikring af indhold. Men som jeg også argumenterer for, er der afgørende forskelle i deres tilgange hertil - forskelle, der for en stor del bunder i deres grundliggende forskellige opdrag og muligheder i relation til brugerautentificering.

20 www.ipernity.com. Denne tjeneste er i øvrigt også interessant, fordi brugeren kan kombinere forskellige medietyper/objekter (altså lave sammensatte objekter). Fx kan man kombinere et billede med en audiosekvens, hvilket fx gør det muligt at lave et alternativ til tekstbaserede billedforklaringer. 
Fx giver det uomtvisteligt de institutionsbaserede løsninger og tjenesterne, der bygger på samlede autentifikations- og autorisationsmekanismer, en række unikke muligheder, at de har fuldstændig styr på, hvem brugerne er. Specielt i relation til at give adgang til beskyttede videoressourcer, men også i forhold til fx etablering af tværinstitutionelle arkiver eller opklaring af ophavsretlige krænkelser, hvor institutionerne har mere vidtrækkende muligheder, end de kommercielle tjenester har. Derudover indebærer institutionernes forsknings- og uddannelsesmæssige opdrag et noget andet fokus på metadata og bevaring end det, de kommercielle tjenester har.

Det betyder imidlertid ikke, at de kommercielle løsninger er irrelevante at se på, når man som underviser, forsker eller institution skal vælge

distributionsløsning. YouTube m.fl. har hævet over enhver tvivl deres berettigelse også i uddannelsesmæssig sammenhæng. Fx i forbindelse med markedsføring af et universitet overfor potentielle studerende - her er YouTube og lignende populære sites for masserne det rigtige sted. Eller fordi de simpelthen passer godt ind i de studerendes eksisterende praksis for teknologianvendelse, som i eksemplet med iTunesU, hvis succes bl.a. må tilskrives, at den er indlejret i en allerede uhyre udbredt platform til mediedistribution af enhver art.

Omvendt vil der være situationer, hvor det er mere formålstjenligt at bruge en distributionstjeneste, der er udviklet til en universitetssammenhæng enten fordi behovet for fx adgangsbegrænsning, udvidede metadateringsmuligheder eller bevaring mv. er tænkt ind. I atter andre situationer er den rigtige strategi at distribuere på begge måder, underforstået at dét, der findes på YouTube, kun er én blandt flere ligeværdige distributionskanaler, eller kun er en smagsprøve, og at der er mere at hente på fx institutionens eget site. Hvad der er den rigtige distributionsstrategi i den givne situation afhænger helt af formidlingsgenre og formål.

Pointen er således ikke, at kommercielle løsninger er noget skidt, men derimod at man bør have et reflekteret forhold til, hvilke distributionsløsninger man bruger hvornår. 